\title{
Study of phenolic extractability in grape seeds by means of ATR- FTIR and Raman spectroscopy
}

\author{
Julio Nogales-Bueno \\ Universidad de Sevilla \\ Berta Baca-Bocanegra \\ Universidad de Sevilla \\ Abigail Rooney \\ Technological University Dublin
}

See next page for additional authors

Follow this and additional works at: https://arrow.tudublin.ie/focasart

Part of the Food Chemistry Commons, and the Physics Commons

\section{Recommended Citation}

Nogales-Bueno J, Baca-Bocanegra B, Rooney A, Hernández-Hierro JM, Byrne HJ, Heredia FJ. Study of phenolic extractability in grape seeds by means of ATR-FTIR and Raman spectroscopy. Food Chem. 2017 Oct 1;232:602-609. doi: 10.1016/j.foodchem.2017.04.049. Epub 2017 Apr 8. PMID: 28490118.

This Article is brought to you for free and open access by the Focas Collaborations at ARROW@TU Dublin. It has been accepted for inclusion in Articles by an authorized administrator of ARROW@TU Dublin. For more information, please contact arrow.admin@tudublin.ie, aisling.coyne@tudublin.ie,gerard.connolly@tudublin.ie. 


\section{Authors}

Julio Nogales-Bueno, Berta Baca-Bocanegra, Abigail Rooney, José Miguel Hernández-Hierro, Hugh Byrne, and Francisco José Heredia 


\title{
Study of phenolic extractability in grape seeds by means of ATR-FTIR and Raman spectroscopy
}

\author{
Julio Nogales-Bueno ${ }^{a}$, Berta Baca-Bocanegra ${ }^{a}$, Abigail Rooney ${ }^{\mathrm{b}}$, José Miguel Hernández-Hierro ${ }^{\mathrm{a}}$, \\ Hugh J. Byrne $^{\mathrm{b}}$, Francisco José Heredia ${ }^{\mathrm{a}, *}$ \\ ${ }^{a}$ Food Colour and Quality Laboratory, Department of Nutrition and Food Science, Facultad de Farmacia, Universidad de Sevilla, 41012 Sevilla, Spain \\ ${ }^{\mathrm{b}}$ FOCAS Research Institute, Dublin Institute of Technology, Kevin Street, Dublin 8, Ireland
}

\section{A R T I C L E I N F O}

\section{Article history:}

Received 22 November 2016

Received in revised form 24 March 2017

Accepted 7 April 2017

Available online 8 April 2017

\section{Keywords:}

Wine

Grape seeds

Phenolic extractability

ATR-FTIR spectroscopy

Raman spectroscopy

Hyperspectral imaging

\begin{abstract}
A B S T R A C T
Near infrared hyperspectral imaging has been applied to grape seeds in order to select a representative subset of samples according to their spectral features in the $900-1700 \mathrm{~nm}$ range. Afterwards, selected grape seeds have been classified according to their total phenol and flavanol extractabilities. In this way, samples were sorted in three different groups identified as low, medium and high extractability levels.

In order to establish the chemical structures which can be responsible for the different extractabilities, vibrational spectroscopy has been applied to the non-extracted material after seed extractions. Attenuated total reflectance Fourier transform infrared (ATR-FTIR) and Raman spectra of non-extracted seed material have been recorded and their main spectral features have been linked to extractabilities of flavanolic and total phenolic compounds.

The vibrational spectroscopic analysis confirms that grape seed phenolic extractability is influenced by the cell wall composition (polysaccharides, lignins, pectins) and by the degree of esterification of pectins.
\end{abstract}

(c) 2017 Elsevier Ltd. All rights reserved.

\section{Introduction}

Although grape seeds represent only $0-6 \%$ of berry weight, they effect the sensory properties of wine. Depending on varieties, they contain between 20 and $55 \%$ of the phenolic compounds of the berry (Ribéreau-Gayon et al., 2006). Phenolic compounds are characterized by having at least one aromatic ring with one or more hydroxyl groups attached. Flavonoids are the most numerous amongst phenolics. The generic structure of the major flavonoids comprises fifteen carbons (C6-C3-C6), with two aromatic rings (C6) connected by a heterocyclic pyran ring of three-carbon bridge (C3). Flavonoids are secondary metabolites that have important and varied roles (Crozier, Clifford, \& Ashihara, 2006), including well-known health benefits. They possess ideal structural

Abbreviations: ATR-FTIR, attenuated total reflectance Fourier transform infrared; DAD, diode array detector; DMACA, 4-dimethylaminocinnamaldehyde; IR, infrared; $\mathrm{H}$, Mahalanobis distance; MSC, multiplicative scatter correction; NEM, non-extracted material; $\mathrm{NH}$, neighborhood Mahalanobis distance; NIR, near infrared; NIRS, near infrared spectroscopy; PC, principal component; PCA, principal component analysis.

* Corresponding author.

E-mail address: heredia@us.es (F.J. Heredia). chemistry for free radical-scavenging activities, and they have been shown to be more effective antioxidants in vitro than vitamins $\mathrm{E}$ and C, on a molar basis (Rice-Evans, Miller, \& Paganga, 1997).

The main subclasses of flavonoids present in grapes (Vitis vinifera L.) are flavonols, flavanols and anthocyanins, and they are transferred to the wine during the fermentation process. Flavonols and anthocyanins are principally localized in the skin, whereas flavanols are synthesized primarily in seeds and stems (Jackson, 2000). Flavanols constitute the most abundant phenolic family in grape seeds and play a relevant role in the sensory characteristic of red wines. They can increase the wine body, but also the sensations of astringency and bitterness (Waterhouse, 2002). Moreover, flavanols, like the main phenolic families, can increase and stabilize the wine color by means of the copigmentation phenomenon (Boulton, 2001; Gordillo et al., 2015; Nogales-Bueno, BacaBocanegra, Jara-Palacios, Hernández-Hierro, \& Heredia, 2017).

The importance of controlling the amount of phenolic compounds that may be extracted from grapes to wine lies in the fact that the phenolic content wine depends mainly on the amount of phenolic compounds released from grape to wine. It is well known that the extractabilities of phenolic compounds from the solid parts of grapes (seeds and skins) depends on the grape maturity. 
However, in skins, phenolic extractability increases with maturity, whereas, in seeds it decreases. (Ribéreau-Gayon et al., 2006).

The effect of cell wall degradation on the degree of extraction of phenolic compounds from grape skins has already been widely studied. Several studies have been developed using this matrix in order to control and understand the relationship between cell wall composition and the extraction degree of phenolic compounds. An increase in the sugar content (degree of ripening) has been correlated with decreasing amounts of cell wall material, galactose, cellulose and mannose, accompanied by a decrease in the degree of methylation of pectic polysaccharides or pectins (Ortega-Regules, Ros-García, Bautista-Ortín, López-Roca, \& Gómez-Plaza, 2008). These factors could be responsible for the different extractabilities of phenolic compounds, bearing in mind that differences on thickness or density of the skin cell-wall could also play a role.

Regarding grape seeds, extractability decreases during ripening, from about $25 \%$ at the first stages to about $5 \%$ in the later (Rodríguez-Pulido et al., 2014). It might be inferred that this phenomenon could be attributed to the presence of the middle integument, which is waterproof and very hard when seeds ripen and lignify, and could prevent the extraction (Cadot, Minana-Castello, \& Chevalier, 2006). On the other hand, changes in the cell wall polysaccharide structure could affect the solubility of the flavanols (Bautista-Ortín et al., 2013). These authors found that maceration enzymes, normally used in the wine elaboration process to degrade skin cell wall in order to increase color, can also favour the extraction of flavanols from the seeds. These oenological products easily degrade the cell walls of seeds (especially if they are unripe and show low lignification), promoting the release of seed compounds into the must-wine, increasing the wine body, but also the sensations of astringency and bitterness. It is therefore of interest to evaluate how cell wall structure changes among seed samples of different grape varieties or with different levels of phenolic compounds extractability.

Near infrared spectroscopy (NIRS) has been used in order to screen total or extractable phenolic compounds in grapes obtaining quite good results (Ferrer-Gallego, Hernández-Hierro, RivasGonzalo, \& Escribano-Bailón, 2011; Kemps, Leon, Best, De Baerdemaeker, \& De Ketelaere, 2010; Nogales-Bueno, BacaBocanegra, Rodríguez-Pulido, Heredia, \& Hernández-Hierro, 2015; Nogales-Bueno, Hernández-Hierro, Rodríguez-Pulido, \& Heredia, 2014; Rodríguez-Pulido et al., 2014; Torchio, Río Segade, Giacosa, Gerbi, \& Rolle, 2013). However, it is not possible to easily interpret the relationship between cell wall composition and phenolic compounds extractability based on near infrared (NIR) region features. The near infrared region contains absorption bands corresponding to overtones and combinations of fundamental $\mathrm{C}-\mathrm{H}, \mathrm{O}-\mathrm{H}$ and $\mathrm{N}-\mathrm{H}$ vibrations. Additionally, the presence of Fermi resonances can also increase the complexity of the NIR spectra. Therefore, many band assignments can only be tentative or unresolved which limits the usefulness of the near infrared region in structural determination. In comparison, mid infrared spectra exhibit sharp and narrow peaks essentially related to fundamental modes of vibration which can be easily assigned to chemical structures (Bokobza, 1998). Mid infrared spectroscopy has previously been used in order to relate skin cell wall composition to anthocyanin extractability (Femenia, Sánchez, Simal, \& Rosselló, 1998; Hernández-Hierro et al., 2014). In these studies, mid infrared spectral features could be directly linked to the esterification of pectins, which might be responsible for the different extractabilities of the aforementioned phenolic compounds. Moreover, this spectroscopic technique has been applied to the study and quantitation of phenolic compounds extracted during winemaking (Di Egidio, Sinelli, Giovanelli, Moles, \& Casiraghi, 2010; Fragoso, Acena, Guasch, Mestres, \& Busto, 2011). However, in these cases, cell wall composition has not been taken into account.
Cell wall structure of grape and other fruits has been widely studied by means of vibrational spectroscopy. Vibrational spectroscopy is a subset of spectroscopy which comprises IR and Raman spectroscopy and analyses vibrations within a molecule (or material) (Byrne et al., 2014). These two vibrational spectroscopic techniques are complementary. Whereas electric dipole transitions of IR (and UV-visible) absorption require a change of the dipole moment of the material as a result of the transition, Raman scattering requires a change in the polarizability of the bond as a result of the transition. Thus, access to molecular level information by means of two different physical processes can be achieved (Byrne, Sockalingum, \& Stone, 2011).

Mid infrared spectroscopy has been employed to study cell wall structure of grapes and other fruits (Acebes et al., 2014; Fasoli et al., 2016; Kyomugasho, Christiaens, Shpigelman, Van Loey, \& Hendrickx, 2015; Wilson et al., 2000; Zietsman et al., 2015). However, studies which employ mid infrared spectroscopy to study the cell wall structure of grapes seeds have not been performed. Raman spectroscopy has also been employed to study cell wall structure in fruits, although, no studies have been found for grapes (Chylińska, Szymańska-Chargot, \& Zdunek, 2014; da Silva, Vandenabeele, Edwards, \& Cappa de Oliveira, 2008; Gierlinger, Keplinger, \& Harrington, 2012; Szymańska-Chargot et al., 2016). Therefore, although both mid infrared and Raman spectroscopy have proved to be useful and reliable techniques for the study of the cell wall structure in plant and fruit tissues, they have not yet been applied to the study of grape seeds.

In the present study, near infrared hyperspectral imaging has been applied to grape seed samples in order to select a representative subset of samples according to their near infrared spectral features. Afterwards, total phenol and flavanol extractabilities have been obtained for these selected samples and they were sorted into three different groups, identified as low, medium and high extractability levels. Next, Raman and attenuated total reflectance Fourier transform infrared (ATR-FTIR) spectra have been collected for non-extracted material after grape seed extractions. Finally, ATR-FTIR and Raman spectra have been analyzed in order to relate their more important features to phenolic extractability levels in grapes seeds. Moreover, spectral features are also related to the principal sample attributes. To our knowledge, this is the first time that ATR-FTIR and Raman spectroscopy are jointly applied to grape seed non-extracted material samples in order to relate their more important spectral features to their phenolic extractability levels.

\section{Material and methods}

\subsection{Samples}

V. vinifera L. cv. Syrah and Tempranillo red grape samples were collected from two vineyards located in the Condado de Huelva Designation of Origin D.O. (Andalusia, Spain). Grapes were collected on two different dates, when Tempranillo and Syrah vineyards were respectively harvested (August 7 and 11, 2014). A total of two hundred Syrah and Tempranillo grapes were collected, one hundred per variety. In order to achieve representative samples sets, single grapes were collected from the top, middle and bottom of the cluster and from the sunlight and shade side. The samples were refrigerated and immediately transported to the laboratory.

\subsection{Sample selection}

Grape seeds were removed from the whole grapes and left to dry at room temperature. Then individual near infrared hyperspectral images were recorded for grape seeds belonging to the same 
grape and the near infrared spectrum was saved (between 950 and $1650 \mathrm{~nm}$ ) as described elsewhere (Rodríguez-Pulido et al., 2014). Afterwards, sample selection was carried out as described in Nogales-Bueno et al. (2015). Briefly, an unsupervised pattern recognition technique, principal component analysis (PCA), was used to select representative samples from the spectral data set. Eight principal components were taken into account in order to explain ninety per cent of the spectral variability of original spectral matrix. Mahalanobis distances $(\mathrm{H})$ for each sample were calculated and samples were grouped according to a neighborhood $\mathrm{H}$ criterion $(\mathrm{NH} \leq 0.6)$. Thus, 66 groups with different spectral characteristics were created and one sample from every group was selected. These 66 selected samples were used in all the subsequent analyses. Grape seeds were weighed, immediately frozen and stored at $-20^{\circ} \mathrm{C}$ until analyses were performed.

\subsection{Model wine and exhaustive extractions}

Two different extractions were carried out: a model wine extraction and an exhaustive extraction.

For model wine extraction, grape seeds were immersed in a model wine hydroalcoholic solution $\left(4 \mathrm{~g} \mathrm{~L}^{-1}\right.$ tartaric acid, $12.5 \%$ $(\mathrm{v} / \mathrm{v})$ ethanol, adjusted at $\mathrm{pH} 3.6$ with $\mathrm{NaOH} 0.5 \mathrm{M}$ ) for a maceration period of $72 \mathrm{~h}$. Then, supernatants were used into the subsequent analyses.

Afterwards, grape seed samples were freeze-dried, grounded and macerated in methanol:water 75:25 (v/v), sonicated during $15 \mathrm{~min}$ (JP Selecta, Barcelona, Spain) and centrifuged $(830 \times \mathrm{g}$, $15 \mathrm{~min}$ ). These extractions were repeated twice in order to achieve an exhaustive extraction of phenolic compounds. The methanolic extracts were combined and finally made up to a final volume of $50 \mathrm{~mL}$ with methanol.

As a by-product of model wine and exhaustive extractions, nonextracted material (NEM) was obtained from each grape seed sample. These NEM samples were freeze-dried and then stored in a desiccator until further use.

\subsection{Total phenol and flavanol extractability determinations}

Total phenol and flavanol extractabilities were determined for grape seed samples. They were determined for each supernatant coming from the model wine and exhaustive extractions. Then, extractabilities of each sample were evaluated, respectively, as the fractions of total phenols and flavanols extracted by the model wine solution with respect to the exhaustive extraction. Finally, grape seed samples were sorted according to their phenolic extractability levels expressed as percentages.

Total phenol contents were determined using the Folin-Ciocalteu method (Singleton \& Rossi, 1965). Two hundred microliters of exhaustive or model wine extractions were mixed with $1.5 \mathrm{~mL}$ of sodium carbonate $(20 \% \mathrm{w} / \mathrm{v}), 500 \mu \mathrm{L}$ of Folin reagent and made up to $10 \mathrm{~mL}$ with ultrapure water.

Flavanol contents were determined following a modification of the method of Vivas, Glories, Lagune, Saucier, and Augustin (1994). Ten or twenty microliters of exhaustive or model wine extractions were mixed with 190 or $180 \mu \mathrm{L}$ of methanol respectively and $1 \mathrm{~mL}$ of DMACA (4-dimethylaminocinnamaldehyde) reagent. The DMACA reagent was prepared immediately before use, containing $0.1 \%(\mathrm{w} / \mathrm{v})$ DMACA in a mixture of $\mathrm{HCl}$ :methanol $(1: 10, \mathrm{v} / \mathrm{v})$.

Both Folin and DMACA analyses were performed on an Agilent 8453 UV-visible spectrophotometer (Palo Alto, USA), equipped with diode array detection (DAD), measuring absorbance at 765 and $640 \mathrm{~nm}$ respectively. The extract volumes were appropriately modified for samples which needed it.

\subsection{ATR-FTIR data collection}

ATR-FTIR spectra were recorded with the Perkin Elmer (MA, USA) Spotlight $400 \mathrm{~N}$ Universal Attenuated Total Reflectance (UATR) accessory of the spectrometer, which employs a 9-bounce diamond top-plate for this analysis. Spectral data were the result of 32 scans, with a spectral resolution of $1 \mathrm{~cm}^{-1}$ and covering the spectral range between 600 and $4000 \mathrm{~cm}^{-1}$.

All samples were measured with a force gauge of 140 units. NEM from grape seed samples were powders and 6 absorption spectra were collected for each grape. A background spectrum was also recorded and automatically subtracted by the software.

\subsection{Raman data collection}

A Horiba Jobin-Yvon LabRAM HR800 spectrometer with an external $300 \mathrm{~mW}$ diode laser operating at $785 \mathrm{~nm}$ as source was used throughout this work. For the measurements, a $\times 100$ objective (MPlanN, Olympus) was employed, providing a spatial resolution of $\sim 1 \mu \mathrm{m}$ at the sample. The confocal hole was set at $100 \mu \mathrm{m}$, the specified setting for confocal operation. The system was spectrally calibrated to the $520.7 \mathrm{~cm}^{-1}$ spectral line of silicon and the intensity response function was corrected using the Standard Reference Material (SRM) No. 2243 of the National Institute of Standards, Boulder, Colorado, USA (NIST SRM 2243, 2242, 2241). The LabRAM system is a confocal spectrometer that contains two interchangeable gratings (300 and 900 lines per mm respectively). In the following experiments, the 300 lines per mm grating was used, giving a spectral dispersion of $\sim 1.5 \mathrm{~cm}^{-1}$ per pixel. The detector used was a 16-bit dynamic range Peltier cooled CCD detector.

All spectra were recorded over the spectral range between 400 and $3500 \mathrm{~cm}^{-1}$ and with a spectral resolution of $\sim 0.9-1.6 \mathrm{~cm}^{-1}$. Six spectra were collected for each NEM from grape seed samples.

\subsection{Data analysis}

K-means cluster analysis of near infrared hyperspectral data was carried out in order to sort grape seed samples according to their phenolic extractability levels (total phenol, flavanol extractabilities). Initial cluster centers were chosen in order to maximize the initial between-cluster distances. Samples were sorted into three groups, low, medium and high phenolic extractability levels. K-means analysis was carried out by means of Statistica v.8.0 software (StatSoft Inc., OK, USA, 2007).

Both ATR-FTIR and Raman raw data needed spectral pretreatments. A multiplicative scatter correction (MSC) was applied to the ATR-FTIR raw data in order to remove the scattering caused mainly by particle size and compaction. Win ISI (v1.50) (Infrasoft International, LLC, Port. Matilda, PA, USA, 2000) software was used for this aim. Baseline correction was applied to Raman raw data. This correction was carried out using MATLAB R2012b (The Mathworks, Natik, MA, USA, 2012) and following the algorithm described elsewhere by Mazet, Carteret, Brie, Idier, and Humbert (2005). This algorithm estimates the background of a spectrum by means of a non-quadratic cost function. Afterwards, this cost function was subtracted from the raw spectra. Asymmetric truncated quadratic was the cost function which gives the best results to estimate background in Raman spectra of NEM from grape seed samples. Moreover, the backgrounds were estimated by a 5 -order polynomial and with thresholds of 0.01 .

Peak heights were calculated for ATR-FTIR and Raman pretreated spectra and PCA was applied to both whole spectral and peak height matrices. Win ISI (v1.50) software was used for PCA of whole spectral matrices, whereas PCA for peak heights matrices was performed by means of Statistica v.8.0 software (StatSoft Inc., OK, USA, 2007). The aforementioned peaks heights for ATR-FTIR 
and Raman were previously obtained from spectra and pre-treated spectra respectively using MATLAB R2012b (The Mathworks, Natik, MA, USA, 2012). Furthermore, univariate analysis of variance (Tukey post hoc test) was applied to find differences in the peak heights (dependent variables) among different factors (extractability levels or grape varieties). The statistically significant level was considered at $\alpha=0.05$. Statistica v.8.0 software was used to develop these analyses.

\section{Results and discussion}

\subsection{Total phenol and flavanol extractability levels}

K-means cluster analysis of near infrared hyperspectral data sorted grape seed samples in three different groups. The analysis allocated samples into groups according to their total phenols and flavanols extractability levels and, afterwards, these groups were named as low, medium and high extractability levels. Table 1 shows the extractability levels of total phenols and flavanols for grape seed samples and the number of samples classified in each cluster by the k-means method.

\subsection{ATR-FTIR data}

Raw average spectra of NEM from grape seed samples with low, medium and high extractabilities are shown in Fig. 1A. MSC pre- treatment was applied to ATR-FTIR spectra and average spectra were calculated for each grape seed NEM sample. Then, the spectra were vector normalized and mean centered. Afterwards, a PCA was applied to this spectral matrix. Overall, the spectral variability explained was 99\% using 13 principal components and Mahalanobis distances for each sample were calculated. Samples were ranked in order of their $\mathrm{H}$ (Mahalanobis) distance from the mean spectrum of the entire sample set and the $\mathrm{H}>3$ criterion was applied in order to look for spectral outliers. Only one H-outlier was found, and it was not taken into account hereafter. Fig. 1B shows the scores of the NEM from grape seed samples in the space defined by the first and second principal components, which described $44.31 \%$ (PC1) and $35.72 \%$ (PC2) of the variability in the data. In the scores plot, the samples are represented by a color code indicating the different extractability levels. It can be seen that medium extractability samples overlap low and high extractability samples. In fact, if medium extractability samples are removed from this plot, it is possible to find some degree of separation between low and high extractability samples (Fig. 1C).

Fig. 1D shows the MSC pre-treated average spectra of NEM from grape seed samples with low and high extractabilities, which are quite similar. Moreover, Fig. 1D shows the loadings of PC1 and PC2. PC1 and PC2 loadings show large variations in several spectral regions which might influence the grape seeds phenolic extractability. For example, in the scores plot, almost all high extractability samples are located in the negative PC2 region

Table 1

Extractability levels of total phenols and flavanols for grape seed samples. Means and standard deviations.

\begin{tabular}{|c|c|c|c|c|c|}
\hline \multirow[t]{3}{*}{ Samples } & \multirow[t]{3}{*}{$\mathrm{n}^{\mathrm{a}}$} & \multicolumn{4}{|c|}{ Extractabilities (expressed as percentage) } \\
\hline & & \multicolumn{2}{|c|}{ Total phenols } & \multicolumn{2}{|c|}{ Flavanols } \\
\hline & & Mean & SD & Mean & SD \\
\hline All & 66 & 28.09 & 20.15 & 42.60 & 25.76 \\
\hline Low & 25 & 8.57 & 5.21 & 15.25 & 9.63 \\
\hline Medium & 28 & 31.16 & 7.72 & 50.45 & 11.03 \\
\hline High & 13 & 59.04 & 12.54 & 78.28 & 7.24 \\
\hline
\end{tabular}

a Number of samples.
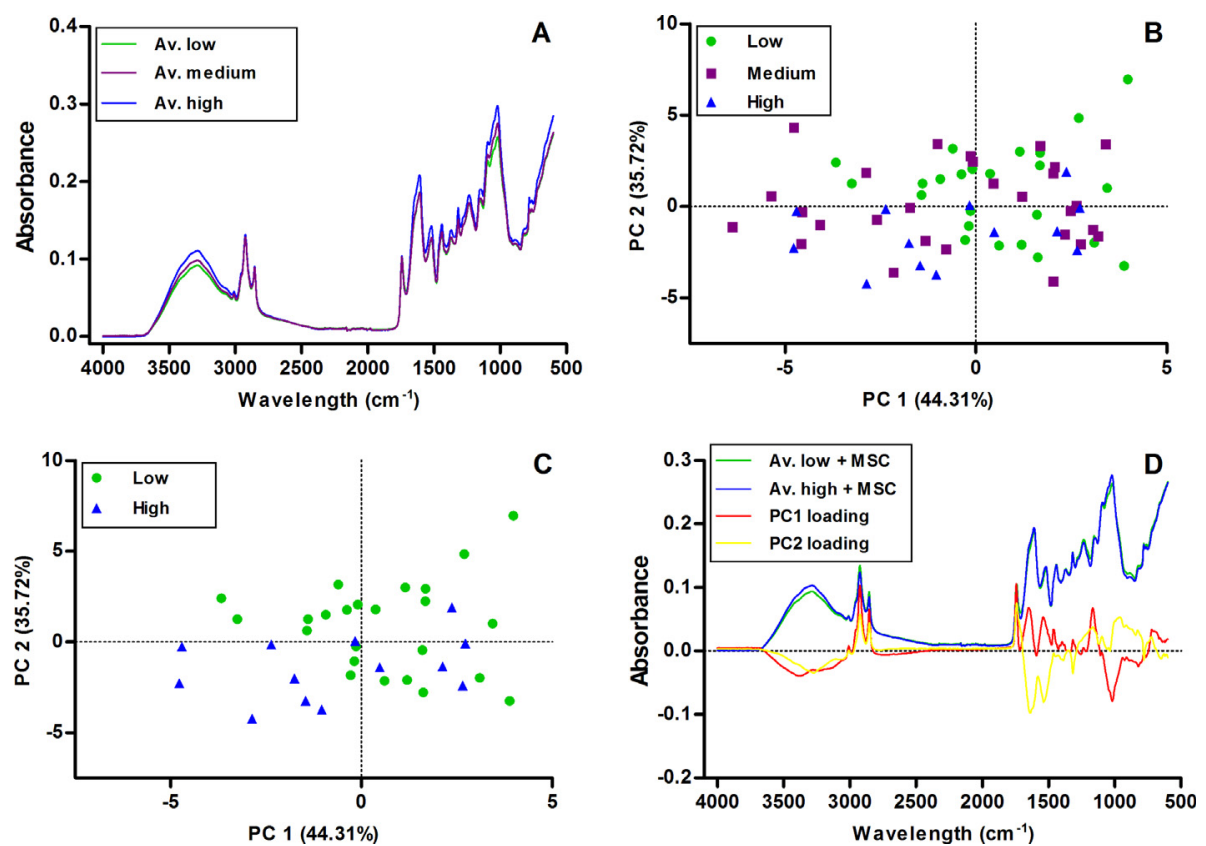

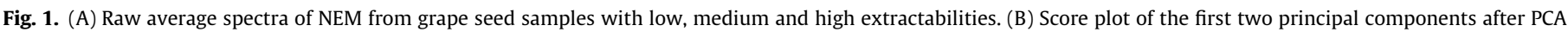

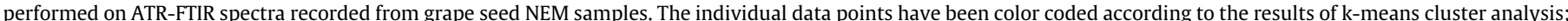

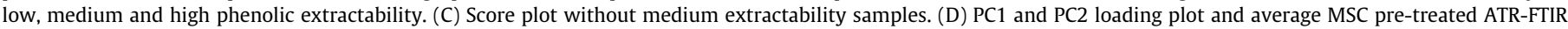
spectra for low and high phenolic extractability grape seed NEM samples. 
Table 2

Main functional groups assigned to the different vibrations present in the ATR-FTIR spectra of non-extracted material (NEM) from grape seed samples.

\begin{tabular}{|c|c|c|c|}
\hline Assignment $^{\mathrm{a}}$ & $\begin{array}{l}\text { Absorption bands }\left(\mathrm{cm}^{-1}\right) \\
\left(\text { Intensity }^{\mathrm{b}}\right)\end{array}$ & Component & References \\
\hline$v(\mathrm{O}-\mathrm{H})$ & $3285(\mathrm{~m}, \mathrm{~b})$ & Polysaccharides, lignins & Heredia-Guerrero et al. (2014), Lupoi, Singh, et al. (2015) \\
\hline$v_{\mathrm{a}}\left(\mathrm{CH}_{2}\right)$ & $2924(\mathrm{~m})$ & Lignins, lipids & Fasoli et al. (2016), Lupoi, Singh, et al. (2015) \\
\hline$v_{\mathrm{s}}\left(\mathrm{CH}_{2}\right)$ & $2854(w)$ & Lignins, lipids & Fasoli et al. (2016), Lupoi, Singh, et al. (2015) \\
\hline$v(\mathrm{C}=\mathrm{O})_{\text {ester }}$ & $1743(\mathrm{~m})$ & Polyesters, pectins, lignins & Fasoli et al. (2016), Szymanska-Chargot and Zdunek (2013), Wilson et al. (2000) \\
\hline $\begin{array}{l}v_{\mathrm{a}}\left(\mathrm{COO}^{-}\right) \text {and } \\
\qquad v(\mathrm{C}=\mathrm{C}) \text { aromatic }\end{array}$ & $1610(s)$ & Pectins, phenolics & $\begin{array}{l}\text { Gao et al. (2015), Ricci et al. (2015), Szymanska-Chargot and Zdunek (2013), Wilson } \\
\text { et al. (2000) }\end{array}$ \\
\hline$v(\mathrm{C}-\mathrm{C})_{\text {aromatic }}$ & $1519(w)$ & Phenolics & Heredia-Guerrero et al. (2014), Lupoi, Singh, et al. (2015) \\
\hline$v(\mathrm{C}-\mathrm{C})_{\text {aromatic }}$ & $1441(w)$ & Phenolics & Foo (1981), Heredia-Guerrero et al. (2014) \\
\hline$\delta\left(\mathrm{CH}_{2}\right)_{\text {out }}$ of plane & $1370(\mathrm{vw})$ & Polysaccharides, pectins & $\begin{array}{l}\text { Lupoi, Singh, et al. (2015), Szymanska-Chargot and Zdunek (2013), Wilson et al. } \\
\text { (2000) }\end{array}$ \\
\hline$\delta\left(\mathrm{CH}_{2}\right)_{\text {scissoring }}$ & $1318(w)$ & Polysaccharides, pectins & Szymanska-Chargot and Zdunek (2013), Wilson et al. (2000) \\
\hline $\begin{array}{l}v(\mathrm{C}-\mathrm{O}) \text { and } \\
\quad \delta(\mathrm{O}-\mathrm{H})\end{array}$ & $1235(w)$ & $\begin{array}{l}\text { Polysaccharides, pectins, } \\
\text { lignins }\end{array}$ & $\begin{array}{l}\text { Lupoi, Singh, et al. (2015), Szymanska-Chargot and Zdunek (2013), Wilson et al. } \\
\text { (2000) }\end{array}$ \\
\hline$v(\mathrm{C}-\mathrm{H})_{\text {aromatic }}$ & $1154(\mathrm{vw})$ & Phenolics & Foo (1981), Lupoi, Singh, et al. (2015) \\
\hline $\begin{array}{l}v(\mathrm{C}-\mathrm{O}) \text { and } \\
\quad v(\mathrm{C}-\mathrm{C})\end{array}$ & $1020(v s)$ & Polysaccharides, pectins & $\begin{array}{l}\text { Lupoi, Singh, et al. (2015), Szymanska-Chargot and Zdunek (2013), Wilson et al. } \\
\text { (2000) }\end{array}$ \\
\hline$\delta\left(\mathrm{CH}_{2}\right)_{\text {rocking }}$ & $781(\mathrm{vw})$ & Phenolics & Foo (1981) \\
\hline
\end{tabular}

a Assignment: $v$, stretching; $\delta$, bending; s, symmetric; a, asymmetric.

b Intensity: vw, very weak; w, weak; m, medium; s, strong; vs very strong; b, broad.

(Fig. 1C), accordingly, the negative features in the PC2 loading (1250-1700 and $3000-3500 \mathrm{~cm}^{-1}$ in Fig. 1D) might have significant influence on phenolic compound extractability. The main features presented for grape seed NEM samples are described in Table 2 . These features are mainly ascribed to polysaccharides, lignins, lipids, pectins and phenolic compounds (Fasoli et al., 2016; Foo, 1981; Heredia-Guerrero et al., 2014; Lupoi, Singh, Parthasarathi, Simmons, \& Henry, 2015; Szymanska-Chargot \& Zdunek, 2013; Wilson et al., 2000).

With the aim of identifying what spectral regions have a major influence on phenolic extractability, a univariate analysis of variance was carried out. Peak heights were measured in MSC pretreated grape seed NEM spectra. Thirteen peaks were taken into account (Table 2). A univariate analysis of variance, a statistical method used to analyze the differences among group means and their associated procedures, was performed. Peak heights were used as dependent variables, whereas extractability level, shown in Table 1, was used as factor or independent variable. This analysis is described in detail in Table 3, which shows the heights (mean and standard error) for all peaks described in Table 2. Moreover, in Table 3, values are marked with letters which indicate the existence or not of statistical differences between extractability levels. No significant differences were found for the peak at $1743 \mathrm{~cm}^{-1}$, ascribed to $(C=O)_{e s t e r}$, and for the peaks at 2854 and $2924 \mathrm{~cm}^{-1}$,

Table 3

Peak heights $(\log (1 / R))$ for different levels of phenolic compounds extractability. Means \pm standard errors of means. For each peak, different letters in the same row indicate statistical differences (Tukey test, $\alpha=0.05$ ).

\begin{tabular}{llll}
\hline \multirow{2}{*}{$\begin{array}{l}\text { Peak wavenumber } \\
\left(\mathrm{cm}^{-1}\right)\end{array}$} & \multicolumn{3}{l}{ Extractability level } \\
\cline { 2 - 4 } & Low & Medium & High \\
\hline 3285 & $0.121 \pm 0.003^{\mathrm{a}}$ & $0.130 \pm 0.002^{\mathrm{b}}$ & $0.143 \pm 0.003^{\mathrm{c}}$ \\
2924 & $0.168 \pm 0.003^{\mathrm{a}}$ & $0.163 \pm 0.003^{\mathrm{a}}$ & $0.162 \pm 0.003^{\mathrm{a}}$ \\
2854 & $0.102 \pm 0.002^{\mathrm{a}}$ & $0.098 \pm 0.002^{\mathrm{a}}$ & $0.097 \pm 0.002^{\mathrm{a}}$ \\
1743 & $0.109 \pm 0.002^{\mathrm{a}}$ & $0.109 \pm 0.002^{\mathrm{a}}$ & $0.112 \pm 0.002^{\mathrm{a}}$ \\
1610 & $0.239 \pm 0.005^{\mathrm{a}}$ & $0.240 \pm 0.004^{\mathrm{a}}$ & $0.267 \pm 0.006^{\mathrm{b}}$ \\
1519 & $0.150 \pm 0.005^{\mathrm{a}}$ & $0.153 \pm 0.004^{\mathrm{a}}$ & $0.172 \pm 0.004^{\mathrm{b}}$ \\
1441 & $0.149 \pm 0.003^{\mathrm{a}}$ & $0.150 \pm 0.002^{\mathrm{a}}$ & $0.163 \pm 0.003^{\mathrm{b}}$ \\
1370 & $0.127 \pm 0.002^{\mathrm{a}}$ & $0.129 \pm 0.002^{\mathrm{a}}$ & $0.140 \pm 0.003^{\mathrm{b}}$ \\
1318 & $0.150 \pm 0.003^{\mathrm{a}}$ & $0.148 \pm 0.003^{\mathrm{a}}$ & $0.166 \pm 0.004^{\mathrm{b}}$ \\
1235 & $0.167 \pm 0.002^{\mathrm{a}}$ & $0.167 \pm 0.002^{\mathrm{a}}$ & $0.179 \pm 0.003^{\mathrm{b}}$ \\
1154 & $0.154 \pm 0.002^{\mathrm{ab}}$ & $0.152 \pm 0.002^{\mathrm{a}}$ & $0.162 \pm 0.002^{\mathrm{b}}$ \\
1020 & $0.267 \pm 0.005^{\mathrm{a}}$ & $0.291 \pm 0.004^{\mathrm{b}}$ & $0.312 \pm 0.006^{\mathrm{c}}$ \\
781 & $0.035 \pm 0.001^{\mathrm{ab}}$ & $0.034 \pm 0.001^{\mathrm{a}}$ & $0.038 \pm 0.001^{\mathrm{b}}$ \\
\hline
\end{tabular}

ascribed to $\mathrm{CH}_{2}$ stretches. Thus, they appear not to have any influence on phenolic compounds extractability. Significant differences $(p<0.05)$ were found for the peaks at 781 and $1154 \mathrm{~cm}^{-1}$, but only
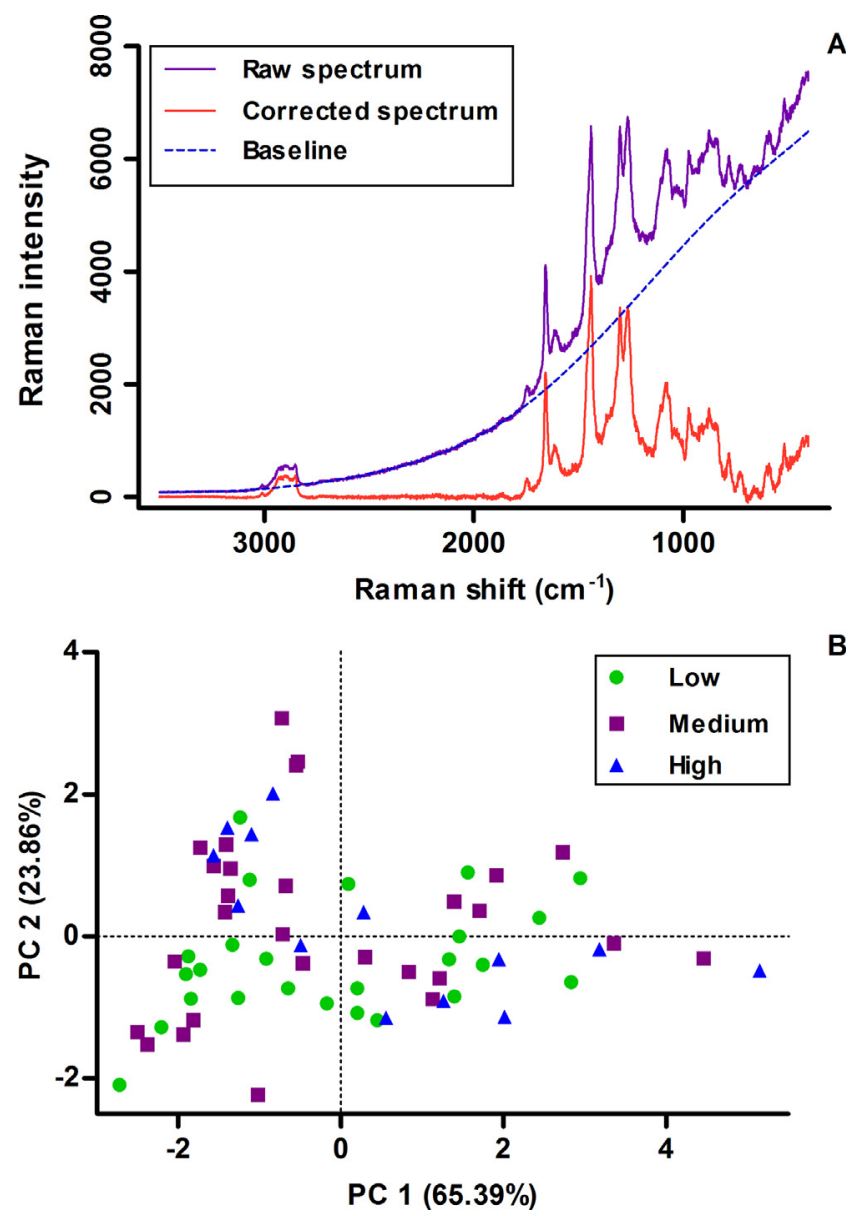

Fig. 2. (A) Raw Raman spectrum, baseline and corrected spectrum for a grape seed NEM sample. (B) Score plot of the first two principal components after PCA performed on peak heights of Raman spectra recorded from grape seed NEM samples. The individual data points have been color coded according to the results of k-means cluster analysis; low, medium and high phenolic extractability. 
Table 4

Main functional groups assigned to the different vibrations present in the Raman spectra of non-extracted material (NEM) from grape seed samples.

\begin{tabular}{|c|c|c|c|}
\hline Assignment $^{\mathrm{a}}$ & $\begin{array}{l}\text { Raman shifts }\left(\mathrm{cm}^{-1}\right) \\
\text { (Intensity }\end{array}$ & Component & References \\
\hline$v\left(\mathrm{CH}_{2}\right)$ & $2916(w, b)$ & Polysaccharides & $\begin{array}{l}\text { Chylińska et al. (2014), Lupoi, Gjersing, et al. (2015), } \\
\text { Szymańska-Chargot et al. (2016) }\end{array}$ \\
\hline$v(\mathrm{C}=\mathrm{C})$ & $1655(\mathrm{~s})$ & Lignins, fatty acids & da Silva et al. (2008); Seidler-Lozykowska et al. (2010) \\
\hline$v(\mathrm{C}=\mathrm{C})$ aromatic & $1609(w)$ & Lignins, phenolics & $\begin{array}{l}\text { da Silva et al. (2008), Gierlinger and Schwanninger (2006), } \\
\text { Seidler-Lozykowska et al. (2010), Sene, McCann, } \\
\text { Wilson, and Grinter (1994) }\end{array}$ \\
\hline$\delta\left(\mathrm{CH}_{2}\right)_{\text {scissoring }}$ & 1442 (vs) & Lignins, lipids & Gierlinger and Schwanninger (2006), Lupoi, Gjersing, et al. (2015), Szymańska-Chargot et al. (2016) \\
\hline$\delta(=\mathrm{CH})_{\text {rocking }}$ & 1269 (vs) & Lipids & da Silva et al. (2008), Gierlinger and Schwanninger (2006), Lupoi, Gjersing, et al. (2015) \\
\hline
\end{tabular}

Assignment: $v$, stretching; $\delta$, bending.

b Intensity: w, weak; s, strong; vs very strong; b, broad.

between medium and high extractability levels. However, no significant differences were found between low and high extractability levels. These two peaks are related to phenolic compounds, and therefore, this fact can show some kind of differentiation between phenolic compounds in medium and high extractability samples, but not between these and low extractability samples. Finally, there are significant differences $(\mathrm{p}<0.05)$ in the remaining peaks, 1020 and $3285 \mathrm{~cm}^{-1}$, between the three extractability levels and between low/medium levels and high level for peaks at 1235 , $1318,1370,1441,1519$ and $1610 \mathrm{~cm}^{-1}$. It is to be noted that almost all these peaks fall within the spectral regions that principal component analysis showed to have significant influence on phenolic compound extractability. Despite the obvious fact that peaks related to the remaining phenolic compounds (1441 and $1519 \mathrm{~cm}^{-1}$ ) (Foo, 1981; Heredia-Guerrero et al., 2014) influence phenolic extractability, these results confirm that phenolic extractability is also influenced by the cell wall composition (peaks at $1020,1235,1318,1370$ and $3285 \mathrm{~cm}^{-1}$ ascribed to polysaccharides, lignins and pectins) and by the degree of esterification of pectins $\left(1610 \mathrm{~cm}^{-1}\right.$, non-esterified pectins) (Gao, Fangel, Willats, Vivier, \& Moore, 2015; Szymanska-Chargot and Zdunek, 2013; Wilson et al., 2000). However, this last peak is also ascribed to $\mathrm{C}=\mathrm{C}$ aromatic stretching in phenolic compounds by other authors (Ricci, Olejar, Parpinello, Kilmartin, \& Versari, 2015).

In addition, using grape variety as factor, a new analysis of variance was carried out and significant differences were found for peaks at 1020,1370, 1441 and $3285 \mathrm{~cm}^{-1}$ among Tempranillo and Syrah samples. All these peaks also have significant influence on the extractability of phenolic compounds. Therefore, these results show that ATR-FTIR spectral features are linked to grape variety and it can be confirmed that this spectroscopic tool can be used to study the relation between grape variety and phenolic compound extractability of grape seeds.

\subsection{Raman data}

In order to confirm or add more information to the above findings, Raman spectra were measured for NEM from grape seeds. A baseline correction procedure was carried out for each grape seed NEM spectrum (Fig. 2A) and 5 peaks were selected, those at 1269, 1442, 1609, 1655 and $2916 \mathrm{~cm}^{-1}$ (Table 4) (Chylinska, SzymanskaChargot, \& Zdunek, 2014; da Silva et al., 2008; Gierlinger \& Schwanninger, 2006; Lupoi, Gjersing, \& Davis, 2015; SeidlerLozykowska, Baranska, Baranski, \& Krol, 2010; SzymanskaChargot et al., 2016). These peaks were selected because they had a good signal to noise ratio and were present in most samples. Then, PCA was performed, both of whole spectra (data not shown) and peak heights (Lupoi, Singh, et al., 2015). The average peak heights were calculated for each sample and PCA was carried out using these data. Fig. 2B shows the scores of the NEM from grape seed samples in the space defined by the first and second principal components, which described $65.39 \%$ (PC1) and $23.86 \%$ (PC2) of the variability in the data. In the scores plot, the samples are represented by a color code indicating the different extractability levels. No trends were found, as samples are overlapped in this space, and thus, PCA cannot be used to interpret the differences between phenolic extractability levels in this case.

Afterwards, one-way univariate analyses of variance were performed. Peak heights were used as dependent variables whereas grape seed variety and extractability levels (Table 1) were used as independent variables or factors in the different analyses. Significant difference $(p<0.05)$ among grape varieties was found for the peak at $1655 \mathrm{~cm}^{-1}$. This peak is related to the $\mathrm{C}=\mathrm{C}$ stretch in lignins and fatty acids. Moreover, significant differences were found for the peaks at 1609, 1655 and $2916 \mathrm{~cm}^{-1}$ when extractability levels were taken into account. These bands are respectively due to phenolic compounds, lignins and polysaccharides (Gierlinger \& Schwanninger, 2006; Lupoi, Gjersing, et al., 2015; Seidler-Lozykowska et al., 2010). The band at $1609 \mathrm{~cm}^{-1}$, assigned to aromatic $\mathrm{C}=\mathrm{C}$ skeletal stretching, has a strong Raman activity, whereas it only weakly active in infrared spectroscopy. However, the anti-symmetric stretching of $\mathrm{COO}^{-}$only has infrared activity (Sene, McCann, Wilson, \& Grinter, 1994). This allows an assignment of this Raman feature $\left(1609 \mathrm{~cm}^{-1}\right)$ to phenolic compounds and not to pectins. Therefore, Raman spectroscopy enables confirmation of the linkage between cell wall components and phenolic extractability in grape seeds.

\section{Conclusion}

ATR-FTIR and Raman spectroscopy have been proven to be effective and reliable tools to relate the more important spectral features to phenolic extractability levels in grape seed and other sample attributes. ATR-FTIR data analysis confirmed that grape seed phenolic extractability is influenced by the cell wall composition (polysaccharides, lignins and pectins) and by the degree of esterification of pectins, despite the obvious fact that peaks related to the remaining phenolics compounds also influence on phenolic extractability. Moreover, the results obtaining from the infrared spectra have been confirmed by Raman spectroscopy. Peaks linked to cell wall composition have been shown to have significant influence on grape seed extractability.

Although FTIR spectroscopy has been applied to grape samples in several studies, to our knowledge, Raman spectroscopy had not been tested in grape seeds in order to study their cell wall structure. Raman spectroscopy has been shown to be a reliable tool for studying cell wall structure in grape seed tissue. Nonetheless, a comprehensive study should be made in order to improve spectra features, i.e., signal to noise ratio or the background produced by fluorescence. 


\section{Funding}

This work was supported by the Spanish MINECO [Grant Nos. BES-2012-060192, EEBB-I-15-09193 and project AGL2014-58486C2]; Universidad de Sevilla [VPPI].

\section{Conflict of interest}

The authors declare no potential conflict of interest.

\section{Acknowledgements}

The authors thank the technical staff of Biology Service [Servicios Generales de Investigación (SGI), Universidad de Sevilla].

\section{References}

Acebes, J. L., Largo-Gosens, A., Hernández-Altamirano, M., García-Calvo, L., AlonsoSimón, A., \& Álvarez, J. M. (2014). Fourier Transform Mid InfraRed spectroscopy applications for monitoring the structural plasticity of plant cell walls. Frontiers in Plant Science, 5.

Bautista-Ortín, A. B., Jiménez-Pascual, E., Busse-Valverde, N., López-Roca, J. M., RosGarcía, J. M., \& Gómez-Plaza, E. (2013). Effect of wine maceration enzymes on the extraction of grape seed proanthocyanidins. Food and Bioprocess Technology, 6(8), 2207-2212.

Bokobza, L. (1998). Near infrared spectroscopy. Journal of Near Infrared Spectroscopy, 6(1), 3-17.

Boulton, R. (2001). The copigmentation of anthocyanins and its role in the color of red wine: A critical review. American Journal of Enology and Viticulture, 52(2), 67-87.

Byrne, H. J., Ostrowska, M. K., Nawaz, H., Dorney, J., Meade, D. A., Bonnier, F., \& Lyng, M. F. (2014). Vibrational spectroscopy: Disease diagnostics and beyond. In M. Baranska (Ed.), Optical spectroscopy and computational methods in biology and medicine (pp. 355-399). Dordrecht, Netherlands: Springer, Netherlands.

Byrne, H. J., Sockalingum, G. D., \& Stone, N. (2011). Chapter 4 Raman microscopy: Complement or competitor? In Biomedical applications of synchrotron infrared microspectroscopy: A practical approach (pp. 105-143). Karlsruhe, Germany: The Royal Society of Chemistry.

Cadot, Y., Minana-Castello, M. T. \& Chevalier, M. (2006). Anatomical, histological, and histochemical changes in grape seeds from Vitis vinifera L. cv Cabernet franc during fruit development. Journal of Agricultural and Food Chemistry, 54 (24), 9206-9215.

Chylińska, M., Szymańska-Chargot, M., \& Zdunek, A. (2014). Imaging of polysaccharides in the tomato cell wall with Raman microspectroscopy. Plant Methods, 10(1), 1-9.

Crozier, A., Clifford, M. N., \& Ashihara, H. (2006). Plant secondary metabolites. Occurrence, structure and role in the human diet. Oxford, England: Blackwell Publishing.

da Silva, C. E., Vandenabeele, P., Edwards, H. G. M., \& Cappa de Oliveira, L. F. (2008). NIR-FT-Raman spectroscopic analytical characterization of the fruits, seeds, and phytotherapeutic oils from rosehips. Analytical and Bioanalytical Chemistry, 392 (7), 1489-1496.

Di Egidio, V., Sinelli, N., Giovanelli, G., Moles, A., \& Casiraghi, E. (2010). NIR and MIR spectroscopy as rapid methods to monitor red wine fermentation. European Food Research and Technology, 230(6), 947-955.

Fasoli, M., Dell'Anna, R., Dal Santo, S., Balestrini, R., Sanson, A., Pezzotti, M.... Zenoni, S. (2016). Pectins, hemicelluloses and celluloses show specific dynamics in the internal and external surfaces of grape berry skin during ripening. Plant \& Cell Physiology, 57(6), 1332-1349.

Femenia, A., Sánchez, E. S., Simal, S., \& Rosselló, C. (1998). Effects of drying pretreatments on the cell wall composition of grape tissues. Journal of Agricultural and Food Chemistry, 46(1), 271-276.

Ferrer-Gallego, R., Hernández-Hierro, J. M., Rivas-Gonzalo, J. C., \& Escribano-Bailón, M. T. (2011). Determination of phenolic compounds of grape skins during ripening by NIR spectroscopy. Lwt-Food Science and Technology, 44(4), 847-853.

Foo, L. Y. (1981). Proanthocyanidins: Gross chemical structures by infrared spectra. Phytochemistry, 20(6), 1397-1402.

Fragoso, S., Acena, L., Guasch, J., Mestres, M., \& Busto, O. (2011). Quantification of phenolic compounds during red winemaking using FT-MIR spectroscopy and PLS-regression. Journal of Agricultural and Food Chemistry, 59(20), 10795-10802.

Gao, Y., Fangel, J. U., Willats, W. G. T., Vivier, M. A., \& Moore, J. P. (2015). Dissecting the polysaccharide-rich grape cell wall changes during winemaking using combined high-throughput and fractionation methods. Carbohydrate Polymers, $133,567-577$.

Gierlinger, N., Keplinger, T., \& Harrington, M. (2012). Imaging of plant cell walls by confocal Raman microscopy. Nature Protocols, 7(9), 1694-1708.

Gierlinger, N., \& Schwanninger, M. (2006). Chemical imaging of poplar wood cell walls by confocal Raman microscopy. Plant Physiology, 140(4), 1246-1254.
Gordillo, B., Rodríguez-Pulido, F. J., González-Miret, M. L., Quijada-Morín, N., RivasGonzalo, J. C., García-Estévez, I., ... Escribano-Bailón, M. T. (2015). Application of differential colorimetry to evaluate anthocyanin-flavonol-flavanol ternary copigmentation interactions in model solutions. Journal of Agricultural and Food Chemistry, 63(35), 7645-7653.

Heredia-Guerrero, J. A., Benítez, J. J., Domínguez, E., Bayer, I., Cingolani, R., Athanassiou, A., \& Heredia, A. (2014). Infrared and Raman spectroscopic features of plant cuticles: A review. Frontiers in Plant Science, 5.

Hernández-Hierro, J. M., Quijada-Morín, N., Martínez-Lapuente, L., Guadalupe, Z. Ayestarán, B., Rivas-Gonzalo, J. C., \& Escribano-Bailón, M. T. (2014). Relationship between skin cell wall composition and anthocyanin extractability of Vitis vinifera L. cv. Tempranillo at different grape ripeness degree. Food Chemistry, $146,41-47$.

Jackson, R. S. (2000). Chemical constituents of grapes and wine. In R. S. Jackson (Ed.), Wine science: Principles, practice and perception (pp. 232-280). San Diego, California: Academic Press.

Kemps, B., Leon, L., Best, S., De Baerdemaeker, J., \& De Ketelaere, B. (2010) Assessment of the quality parameters in grapes using VIS/NIR spectroscopy Biosystems Engineering, 105(4), 507-513.

Kyomugasho, C., Christiaens, S., Shpigelman, A., Van Loey, A. M., \& Hendrickx, M. E. (2015). FT-IR spectroscopy, a reliable method for routine analysis of the degree of methylesterification of pectin in different fruit- and vegetable-based matrices. Food Chemistry, 176, 82-90.

Lupoi, J. S., Gjersing, E., \& Davis, M. F. (2015). Evaluating lignocellulosic biomass, its derivatives, and downstream products with raman spectroscopy. Frontiers in Bioengineering and Biotechnology, 3(50).

Lupoi, J. S., Singh, S., Parthasarathi, R., Simmons, B. A., \& Henry, R. J. (2015). Recent innovations in analytical methods for the qualitative and quantitative assessment of lignin. Renewable and Sustainable Energy Reviews, 49, 871-906.

Mazet, V., Carteret, C., Brie, D., Idier, J., \& Humbert, B. (2005). Background removal from spectra by designing and minimising a non-quadratic cost function. Chemometrics and Intelligent Laboratory Systems, 76(2), 121-133.

Nogales-Bueno, J., Baca-Bocanegra, B., Jara-Palacios, M. J., Hernández-Hierro, J. M., \& Heredia, F. J. (2017). Evaluation of the influence of white grape seed extracts as copigment sources on the anthocyanin extraction from grape skins previously classified by near infrared hyperspectral tools. Food Chemistry, 221, 1685-1690.

Nogales-Bueno, J., Baca-Bocanegra, B., Rodríguez-Pulido, F. J., Heredia, F. J., \& Hernández-Hierro, J. M. (2015). Use of near infrared hyperspectral tools for the screening of extractable polyphenols in red grape skins. Food Chemistry, 172, 559-564.

Nogales-Bueno, J., Hernández-Hierro, J. M., Rodríguez-Pulido, F. J., \& Heredia, F. J. (2014). Determination of technological maturity of grapes and total phenolic compounds of grape skins in red and white cultivars during ripening by near infrared hyperspectral image: A preliminary approach. Food Chemistry, 152, 586-591.

Ortega-Regules, A., Ros-García, J. M., Bautista-Ortín, A. B., López-Roca, J. M., \& Gómez-Plaza, E. (2008). Changes in skin cell wall composition during the maturation of four premium wine grape varieties. Journal of the Science of Food and Agriculture, 88(3), 420-428.

Ribéreau-Gayon, P., Dubourdieu, D., Doneche, B., Lonvaud, A., Glories, Y., Maujean, A., \& Branco, J. M. (2006). Handbook of enology, the microbiology of wine and vinifications. West Sussex, England: J. Wiley \& Sons.

Ricci, A., Olejar, K. J., Parpinello, G. P., Kilmartin, P. A., \& Versari, A. (2015) Application of Fourier transform infrared (FTIR) spectroscopy in the characterization of tannins. Applied Spectroscopy Reviews, 50(5), 407-442.

Rice-Evans, C. A., Miller, J., \& Paganga, G. (1997). Antioxidant properties of phenolic compounds. Trends in Plant Science, 2(4), 152-159.

Rodríguez-Pulido, F. J., Hernández-Hierro, J. M., Nogales-Bueno, J., Gordillo, B., González-Miret, M. L., \& Heredia, F. J. (2014). A novel method for evaluating flavanols in grape seeds by near infrared hyperspectral imaging. Talanta, 122, $145-150$.

Seidler-Lozykowska, K., Baranska, M., Baranski, R., \& Krol, D. (2010). Raman analysis of caraway (Carum carvi L.) single fruits. Evaluation of essential oil content and its composition. Journal of Agricultural and Food Chemistry, 58(9), 5271-5275.

Sene, C., McCann, M. C., Wilson, R. H., \& Grinter, R. (1994). Fourier-transform Raman and Fourier-transform infrared spectroscopy (an investigation of five higher plant cell walls and their components). Plant Physiology, 106(4), 1623-1631.

Singleton, V. L., \& Rossi, J. A. (1965). Colorimetry of total phenolics with phosphomolybdic-phosphotungstic acid reagents. American Journal of Enology and Viticulture (16), 144-158.

Szymańska-Chargot, M., Chylińska, M., Pieczywek, P. M., Rösch, P., Schmitt, M. Popp, J., \& Zdunek, A. (2016). Raman imaging of changes in the polysaccharides distribution in the cell wall during apple fruit development and senescence. Planta, 243(4), 935-945.

Szymanska-Chargot, M., \& Zdunek, A. (2013). Use of FT-IR spectra and PCA to the bulk characterization of cell wall residues of fruits and vegetables along a fraction process. Food Biophysics, 8(1), 29-42.

Torchio, F., Río Segade, S., Giacosa, S., Gerbi, V., \& Rolle, L. (2013). Effect of growing zone and vintage on the prediction of extractable flavanols in winegrape seeds by a FT-NIR method. Journal of Agricultural and Food Chemistry, 61(38) 9076-9088.

Vivas, N., Glories, Y., Lagune, L., Saucier, C., \& Augustin, M. (1994). Estimation du degré de polymérisation des procyanidines du raisin et du vin par la méthode 
au p-dimethylaminocinnamaldéhyde. Journal International des Sciences de la Vigne et du Vin, 28, 319-336.

Waterhouse, A. L. (2002). Wine phenolics. New York, New York: The New York Academy of Sciences.

Wilson, R. H., Smith, A. C., Kačuráková, M., Saunders, P. K., Wellner, N., \& Waldron, K. W. (2000). The mechanical properties and molecular dynamics of plant cell wall polysaccharides studied by Fourier-transform infrared spectroscopy. Plant Physiology, 124(1), 397-406.

Zietsman, A. J. J., Moore, J. P., Fangel, J. U., Willats, W. G. T., Trygg, J., \& Vivier, M. A. (2015). Following the compositional changes of fresh grape skin cell walls during the fermentation process in the presence and absence of maceration enzymes. Journal of Agricultural and Food Chemistry, 63(10), 2798-2810. 